\title{
ERGONOMICS, SUSTAINABILITY AND PERFORMANCE
}

\author{
Violeta FIRESCU ${ }^{a^{*}}$ \\ ${ }^{a}$ Technical University of Cluj-Napoca, Romania
}

\begin{abstract}
In the context of the global crisis there is an increasing interest regarding sustainability. While the focus of debate was at the beginning mainly on society level, sustainability issues have currently a growing relevance for social and economic organizational performance. The paper aims to present arguments for considering ergonomics as a support for organizational sustainability. Based on sustainability reports and ergonomics literature review, the paper highlights the essential role of work systems' ergonomic design and finds supporting arguments about ergonomics interventions' impact on organizational performance. The contribution of the paper focuses on helping companies and top managers to understand the impact of ergonomics interventions on decreasing social and economic costs, related especially to occupational health and safety hazard prevention.
\end{abstract}

KEYWORDS: ISO 45001, macroergonomics, new technology, occupational health, work system.

\section{DOI: 10.24818/IMC/2021/04.16}

\section{INTRODUCTION}

Ergonomics and corporate sustainability actions have a significant impact on both economic and social organizational performance. Sustainability represents the framework within which organizations give meaning to their actions (set missions) through a strategic systemic approach. This approach allows trends' analysis in the social - economic - environment trinomial, in order to predict changes and to act before they take place (Hitchcock \& Willard, 2006). Seeing businesses under sustainability's magnifying glass - the business economic impact and business impact on the environment and the community - allows the identification of threats and opportunities which would otherwise remain hidden.

Ergonomics and sustainability have a common goal in increasing employees' well-being and occupational health. As Bolis et al. (2020, p. 2) points out, "there is a need for a better understanding of how they interrelate and can support decision-making". In this context, the aim of the research is to find and present arguments for considering ergonomics as a support for organizational sustainability and performance. Based on the literature and sustainability reports review, some of examples presented in the research report refers to companies included in Dow Jones Sustainability World Index 2020 and highlights the impact of work systems ergonomic design and ergonomics interventions on organizational performance.

Ergonomics - known also as human factors - is both a scientific discipline that aims to understand the human-works system elements' interactions, and a profession that applies specific knowledge (theories, principles, data, and methods) "to design in order to optimize human well-being and overall system performance" (https://iea.cc). As Dul et al. (2012, p. 392) noted, the name HFE human factors/ergonomics is used to show that HFE is "a scientific discipline and not only a (multidisciplinary) approach to problem solving". Due to the "power of habit", this paper uses the term ergonomics for referring to human-centered integrated design of work systems.

*Corresponding author. E-mail address: violeta.firescu@mis.utcluj.ro 


\section{BACKGROUND}

\subsection{Sustainable development and macroergonomics}

"Sustainable Development Goals 2030" concept, defined in 2015, includes in the 2030 Agenda Sustainable Development Goal 9 (SDG 9): the sustainable industrial development, the creation of a resilient infrastructure and innovation (https://sustainabledevelopment.un.org), the foundation of the sustainable economic growth being represented by a sustainable and inclusive industrial development. To support industrial development, the sustainable development of businesses involves adding value and raising the degree to which scientific discoveries, new technologies and innovations in the field are applied. Introducing new ideas and technologies contributes to the development of new workplaces, to the increase of work productivity and to the efficient use of resources (https://ec.europa.eu). It also leads to the need of investing in people by developing abilities and educational programs that would prepare the human resource to handle the challenges of the future.

As Firescu and Cândea (2007, p. 107) shows, macroergonomics (organizational ergonomics) places a strong emphasis "on the human factor, motivation, teamwork, ethics, etc. that play an important role in achieving long-term business prosperity" and contributes to the sustainable economic growth by developing resilient infrastructures, systems, and processes (understanding by it, the capacity to "strengthen" in long term and cope with unfavorable events).

Discussing about the industrial modern workplace design, including human - machines interface design, Kinzel (2016) highlights the need for employees' involvement in the system's design phase in order to easier accept future changes. From the practical point of view, a human factor-centered design means adaptability and the use of the mediation process, traditionally used in conflict management. Stakeholders' communication is one essential aspect to the understanding and acceptance of requirements of all interested parties: system developers, system users (employees) and customers (society) and the specialist in ergonomics "has a training and experience as a mediator" (Kinzel, 2016, p. 80).

Especially in the context of the global crisis, the neglect of the human factor may lead to the failure of today more and more complex systems.

\subsection{Sustainability and performance}

To be competitive, companies have as main target the reduction of costs, on one hand, but also the elimination of squandering through the work process, reflected in absenteeism, downtime, error occurrence etc., on the other hand. The employee working in industrial production needs to perform, in particular situations, unpleasant, repetitive tasks, which could affect its health and motivation. The effect of these tasks is reflected in various situations, from low productivity, insufficient quality, to the employees' injury and illness. Robots could be the solution, because "robots are generally used to perform highly repetitive tasks, unsafe and unpleasant tasks" (Covaciu \& Filip, 2019). However, the costs for introducing new technologies need to be justified by the (financial, salary related, etc.) savings that will be obtained.

The use of new technology (such as automation, robots, or artificial intelligence) may contribute to sustainability and to the fight against climate changes and stimulates the development of a highly qualified workforce. A few arguments to sustain these ideas are presented below:

(a) Port automation, at one of the 22 terminals in Port of Long Beach (USA), favored the use of energy generated by natural gas or of renewable energy, leading to "zero emissions" processes. The human resource was significantly reduced (two-thirds fewer workers), and opportunities for new work positions (mechanics to maintain the self-driving vehicles) were created. In addition, robots are considered to be polluting less than the machines previously controlled by people. (Guerin, 2018). 
(b) The use of IoT (Cyber Physical System, Cyber-Physical Production System and Big Data Technologies) in the value chain of some Hungarian companies led to the improvement of their logistic services' quality and that of the processes, a better financial and market performance and a raised competitivity, as Nagy et al. (2018) shows.

(c) Industry 4.0 approach offers a strategic and business model for maintaining and extending a company's competitive position. Analyzing the tendency in implementing Industry 4.0 in German companies, Müller et al. (2018) emphasized their positive effect and relevant benefits, because companies make considerable efforts to gain competitive advantages and long-term success.

(d) In an analysis of the five most important German industries, Kadir et al. (2019) identified the Industrial Internet of Things (IIoT) impact and the changes that occurred in the business model of each industry. Thus, for companies in the field of machine and installation building, (machine and plant engineering companies) the main challenge is to change the qualification of the workforce.

The use of new technology sustains the organizational economic performance and company's competitive position and creates the context to find and implement human resources strategies for workforce development. Firescu et al. (2020) emphasized that the use of new complex technologies in organizations brings new challenges for human resources management and mentioned a list of continuing education programs related to performance: ergonomics, technological novelty, and vitality management (such as: work-life balance, health and vitality, overwork avoidance). Furthermore, to ensure the success of the use of the new technology, companies from different business sectors and top managers needs to adopt a macroergonomics oriented strategy, to improve and redesign the work systems, to develop specific work procedures and to perform of new risks analysis, especially related to occupational health and safety.

To measure corporate sustainability and sustain investors to analyze the organization' performance and its sustainable future, Dow Jones Sustainability Index offers "an unmatched level of clarity and confidence" (https://www.spglobal.com/esg/about/index). Furthermore, an increasing number of companies worldwide voluntarily adopt and accomplished environmental, social and governance (ESG) practices trying "to integrate sustainability into their strategy, business models, and organizational processes and structures" (Ioannou \& Serafeim, 2019).

\section{RESEARCH PROBLEM AND METHODOLOGY}

The global COVID-19 medical crisis brought changes in work systems' design and with them new challenges for companies related to work systems' security, occupational health, and employees' well-being at work.

As mentioned before, there is a need to understand how ergonomics interrelates with sustainability (Bolis et al., 2016), to find solutions and to present recommendations that support decision-making. Also, Zink (2014, p.131) highlights the need "for a different understanding of the overall performance of a company... following the discussion about corporate social responsibility".

Having as a starting point the actual need of companies to clarify the meaning of their future actions and improvements related to ergonomics, the research aims to identify and present arguments for considering ergonomics as a support for sustainability.

Having in mind the results obtained using a security based' leadership by the Alcoa company CEO Paul O'Neill between 1987 and 2000 (as it can be seen in Table 1), the research problem focuses on identifying data on how security, safety, ergonomics and occupational health interventions influence social and economic performance mentioned by companies in their sustainability reports.

The main objective was to undertake a critical bibliographic study that highlights the impact of ergonomics interventions on decreasing costs and improving performance - investments, actions 
and programs mentioned by companies in their sustainability reports and related especially to occupational health and safety hazard prevention.

Table 1. Data and facts about Alcoa company' social, brand and economic performance

\begin{tabular}{|c|c|c|}
\hline & Moment & Ergonomics health and safety practices, impact, or results \\
\hline 1 & $\begin{array}{l}2000 \text { (Paul O’Neill } \\
\text { leadership results) }\end{array}$ & $\begin{array}{l}\text { Decreased: number of accidents, risk of accidents, costs, and } \\
\text { loss of raw material } \\
\text { Increased: product quality, labor productivity, annual net } \\
\text { income ( } 5 \text {-fold increase), capitalization on the financial } \\
\text { market, brand image }\end{array}$ \\
\hline 2 & $\begin{array}{c}\text { Alcoa Sustainability } \\
\text { Report } 2004 \text { (Social } \\
\text { Responsibility) }\end{array}$ & $\begin{array}{l}20 \% \text { of the recorded incidents were associated with } \\
\text { ergonomics in } 2000 \text {. } \\
\text { The first } 10 \text { ergonomic risks were identified. } \\
50 \% \text { of them were eliminated by } 2003 \text {. } \\
\text { The percentage of incidents associated with ergonomics had } \\
\text { decreased to } 15 \% \text {, by } 2004 \text {. }\end{array}$ \\
\hline 3 & $\begin{array}{c}\text { Alcoa Sustainability } \\
\text { Report } 2015 \text { (Social } \\
\text { Responsibility, } \\
\text { Health and Safety) }\end{array}$ & $\begin{array}{l}\text { The desideratum "zero accidents and fatal and serious } \\
\text { diseases" is possible: a safety culture, "the value of human life } \\
\text { above all else". (Alcoa, 2015) } \\
\text { Incident reduction by eliminating hazards, implementing } \\
\text { protection and control methods, reducing human error. }\end{array}$ \\
\hline 4 & $\begin{array}{c}\text { Alcoa Sustainability } \\
\text { Report } 2020 \text { (Health } \\
\text { Hazard Controls) }\end{array}$ & $\begin{array}{l}\text { They declare to continue the work to "reinvigorate the } \\
\text { strategies around ergonomics and work design". In relation to } \\
\text { human resources management, the report mentions "virtual } \\
\text { ergonomic consults for employees working from home" as a } \\
\text { key action to COVID- } 19 \text { response (Alcoa, 2020, pp. } 73 \text { \& 7) }\end{array}$ \\
\hline
\end{tabular}

Source: adapted from Duhigg (2016), Alcoa Sustainability reports $(2004,2015,2020)$

The methodology used to support the research objectives followed the following steps:

(1) defining the research problem

(2) planning the process

(3) analyzing the data and formulating conclusions

To determine the ergonomics interventions impact on organizational performance, more than 20 sustainability reports were checked using keywords such as: ergonomics, ISO 45001, OHSAS, health, occupational or well-being.

To maintain the research' focus on organizational performance, the companies included in the study were selected from the following data sources: The 2020 Sustainability Leaders (Dow Jones), Dow Jones Sustainability World Index 2020 and 2020 Global 100 ranking (Corporate Knights). The companies' websites and web articles related to ergonomics interventions within the selected companies were used.

The study focused on companies from industrial sectors, such as: auto-components, automobiles, materials industry (aluminum), household products and renewable energy solutions. To include a company in the study, the next steps were followed:

(1) The 2020 Sustainability Leaders (Dow Jones) was checked to identify the industry leader.

(2) The leader' sustainability report and Dow Jones ranking score in Occupational Health and Safety (S\&P OHS score) were checked to identify data related to ergonomics interventions publicly mentioned in the documents. When S\&P OHS' industry leader score was very close or equal to S\&P OHS' industry score, the company was included in the study.

(3) When S\&P OHS' industry leader score was above S\&P OHS' industry score, Dow Jones Sustainability World Index 2020 was checked to identify the company ranked as the second 
sustainable company in the industry. If S\&P OHS' industry leader was not included in Dow Jones Sustainability World Index 2020, other companies from the industry were checked to identify data related to ergonomics interventions publicly mentioned in the documents (sustainability reports, company website and articles).

(4) At the end, the sustainability leader mentioned by 2020 Global 100 ranking (Corporate Knights) was included in the study.

\section{FINDINGS AND RESULTS}

The next part of the paper presents the results of the critical bibliographic study concerning the ergonomics interventions, actions, programs, and investments, mentioned by seven sustainable companies in their sustainability reports. The data collected during literature review were grouped in four categories, based on the mentioned aim of the interventions, as follows: (1) ergonomics interventions for prevention and reducing occupational risks, (2) ergonomics existent solutions used in finding solutions in COVID-19 crisis, (3) ergonomics interventions for improving gender diversity and (4) ergonomics interventions for employees' well-being.

\subsection{Ergonomics interventions for prevention and reducing occupational risks}

In the beginning of the study, the 2020 Sustainability Leaders (Dow Jones) was checked to identify the industry leaders in Automobiles \& Components industry.

In auto components industry, Pirelli company was identified as the 2020 sustainability leader, with a S\&P OHS score close to S\&P OHS' industry score. The company is "official partner of the European Agency for Safety and Health at Work (EU-OSHA)" and participates to the 2020-2022 campaign "Healthy Workplaces Lighten the Load" for the twelfth consecutive year (Pirelli, 2020, p. 150). The mentioned programs related to ergonomics focuses on sources of occupational disease and "reducing the risk at source" by identifying ergonomic risks, using "automation and design integrated with the ergonomic requirements of machines". The continuous improvement actions are "complemented by training and organizational measures to encourage safety and prevention behavior" (Pirelli, 2020, p. 145).

The company has invested in health and safety work systems, with the following targets (Pirelli, 2020, p. 146): (1) improvement of the workplace environment: microclimate, lighting and changes in layout and ergonomic improvement of activities and (2) improvements on machines and plants. In automobiles industry, BMW Group was identified as the 2020 sustainability leader, with a S\&P OHS score close to S\&P OHS' industry score. The sustainability report mentions staff regular training related to occupational health and safety, the BMW Group Academy being responsible to prepare seminars "in cooperation with the relevant departments for occupational safety, ergonomics, environmental protection and health management responsible" (BMW Group, 2020, p. 115). The report also mentions the collaboration between employer and employee representatives within Health and safety committees, for continuous improvements based on OHSAS 18001 and ISO 45001, occupational health and safety management systems standards.

Because S\&P OHS' industry leaders score was above S\&P OHS' industry score, Dow Jones Sustainability World Index 2020 was checked to identify the company ranked in the second place.

General Motors company was identified as the second sustainable company in Automobiles \& Components industry. As General Motors (2020, p. 79) highlights, "ergonomically correct workspaces are a priority at manufacturing facilities around the world". In this regard, ergonomic criteria for workplace design are used and "job positions are evaluated using screening tools". For workplace evaluations, methods like "Risk Factor Checklist, Global Ergonomic Screening Tool, National Institute for Occupational Safety and Health (NIOSH) Lifting Equation and the Occupational Repetitive Action tool" are mentioned. In connection with workplace safety systems, the report mentions the use of standards such as OSHAS 18001, ISO 45001 or standards focused on 
having healthy working environments for employees (ergonomic programs for noise control and indoor air quality programs).

To conclude, as shown above, in Automobiles \& Components industry companies' investments in ergonomics and health security programs are linked to occupational disease control, prevention and reducing occupational risks at source.

\subsection{Ergonomics existent solutions used in finding solutions in COVID-19 crisis}

In household products industry, as mentions the 2020 Sustainability Leaders (Dow Jones), ColgatePalmolive leads the corporate sustainability ranking. As the sustainability report mentions, the health and safety issues target the employees, the customers, and the communities in which company operates, being paramount in all actions based on the company goal "zero harm" (Colgate-Palmolive, 2020, p. 31).

In relation to safety, the sustainability report highlights the EHS (Environment Health Safety) technologies used to find COVID-19 solutions. To assess and fast-track technology solutions was established a cross-functional team that "vetted a contact tracing/social distancing application that also has functionality to alert individuals of at-risk ergonomic positions". Thus, the ergonomics existent solutions have offered a quick response to address the technology needs in the context of the global COVID-19 medical crisis, "while establishing longer term solutions that address EHS or operational needs" (Colgate-Palmolive, 2020, p. 34).

\subsection{Ergonomics interventions for improving gender diversity}

In materials industry (aluminum), Hindalco Industries Ltd was identified as the 2020 sustainability leader, with a S\&P OHS score above S\&P OHS' industry score. The industry leader and other company from this sector were not included in 2020 Dow Jones Sustainability World Index.

In this case, having in mind the results obtained using a security based' leadership by the Alcoa company, "a global industry leader in bauxite, alumina, and aluminum products" (Dwyer \& Beck, 2020), the research focused on identifying new data on how security, safety, ergonomics, and occupational health' interventions influence social and economic performance publicly mentioned in Alcoa sustainability report. Dwyer \& Beck (2020) mentions Alcoa company inclusion in the 2020 Dow Jones Sustainability Indices, after its exit in 2013 from Dow Jones (Trefis, 2013).

In addition to the aspects mentioned in Table 1, the sustainability report highlights the ergonomics intervention impact in creating "an inclusive and diverse work environment" for improving gender diversity. A totally masculine workplace, where a woman would be unable to operate before ergonomics intervention, was redesigned and adjustments to the equipment were implemented "to improve ergonomics and attract male and female employees" (Alcoa, 2020, p. 61).

To conclude, as shown above, in materials industry (aluminum) investments in ergonomics and health programs are linked to improve gender diversity, besides prevention, reducing occupational risks and finding solutions for the employees virtual ergonomic consulting in the context of remote working and global COVID-19 medical crisis.

\subsection{Ergonomics interventions for employees' well-being}

At the end, Ørsted company, the sustainability leader in 2020 Global 100 ranking (Corporate Knights), was included in the study. The sustainability report mentions the standard ISO 45001 for operational sites management systems certification and two programs related to ergonomics:" Workplace safety" and" Employee health and well-being". In relation to safety, health, and wellbeing business practices, it is mentioned the managers' training to support them in "science-based stress prevention, and use data and research to develop health and well-being initiatives" (Ørsted, 2020, pp. 38-39).

As demonstrated Flokk (n.d.), Ørsted new office in Warsaw was designed to reflect the company values, using sustainable 3R's principle (Reduce, Reuse and Recycle) for workplace design. The 
criteria and principles of ergonomics design were used to create offices that provide the basic components of employee well-being: physical and mental comfort and contact with nature. The design solution combines biophilic design with ergonomics and aesthetics, including height adjustable chairs able to fit both high and low desks. The sustainable human centered solution offers a functional workspace, flexibility to reconfigure spaces easily from individual to collaborative workspaces, an environment that promoted wellbeing and an environmentally friendly solution for work systems design.

\section{CONCLUSIONS AND RECOMMENDATIONS}

The research presented in this paper was aimed to find and present arguments to consider ergonomics interventions as a support for organizational sustainability and performance. The research findings confirm that ergonomics investments, actions and programs are mentioned in sustainability reports of top sustainable companies in business sectors like auto-components, automobiles, materials industry (aluminum), household products and renewable energy solutions industry.

The research limitations are related to the number of companies and business sectors included in the present study. In the future, we propose to extend the research to top sustainable companies in other business sectors. Another interesting research direction regards the business sectors that are ranked based on Occupational Health and Safety Dow Jones score (e.g., throughout the duration of the research presented in this paper we observed that S\&P OHS score is not used for companies in banks and consumer services industries).

The main results show that companies' investments in ergonomics and health security programs are linked to occupational disease control, prevention and reducing occupational risks, creating healthy working environment, and developing occupational health and safety management systems based on OHSAS 18001:2008 and ISO 45001:2018 (since March 2021). Furthermore, the research results show that ergonomics interventions impact the organizational social performance (e.g., the ergonomic design of work systems allow gender diversity, or the ergonomic biophilic design of workplaces allows employees well-being). The research results lead to the following recommendations for Romanian companies and top managers, to clarify the meaning of their future actions related to ergonomics, human resources management and occupational health and safety:

(1) Managers and employees' training in ergonomics, to help them "to see" possibilities for improving organizational performance.

(2) Coaching and consulting in ergonomics, "to find" possibilities for organizational performance enhancement.

(3) Collaborative research in ergonomics, "to offer" new solutions for workplaces and work systems health, security, and well-being.

\section{REFERENCES}

Alcoa. (2004). European Sustainability Report. Retrieved June 17, 2007, from http://www.alcoa.com/global/en/about_alcoa/commitment_to_sustain/PDFS/Alcoa_Umweltb ericht_Web2.pdf

Alcoa. (2015). Sustainability Report. Retrieved October 24, 2016, from https://www.alcoa.com/sustainability/en/pdf/Alcoa-Sustainability.pdf

Alcoa. (2020). Sustainability Report. Retrieved May 24, 2021, from https://www.alcoa.com/sustainability/en/pdf/2020-Sustainability-Report.pdf

BMW Group. (2020). BMW Group Report. Our responsibility. Our future. Retrieved May 24, 2021, from https://report.bmwgroup.com/home/start/ 
Bolis, I., Morioka, S. N., Brunoro, C. M., Zambroni-de-Souza, P. C., \& Sznelwar, L. I. (2020). The centrality of workers to sustainability based on values: Exploring ergonomics to introduce new rationalities into decision-making processes. Applied Ergonomics, 88, 103148. https://doi.org/10.1016/j.apergo.2020.103148

Colgate-Palmolive. (2020). Reimagining a Healthier Future for All. Retrieved May 24, 2021, from https://www.colgatepalmolive.com/content/dam/cp sites/corporate/corporate/en_us/corp/locale-assets/pdf/colgate-sustainability-and-socialimpact-report-2020.pdf

Corporate Knights. (2020). 2020 Global 100 ranking. Retrieved May 24, 2021, from https://www.corporateknights.com/rankings/global-100-rankings/2020-global-100rankings/2020-global-100-ranking/

Covaciu, F., \& Filip, D. (2019). Design and manufacturing of a 6 degree of freedom robotic arm. Acta Technica Napocensis, 62, 107-114.

Duhigg, C. (2016). Puterea obișnuinței [The Power of Habit]. Publica.

Dul, J., Bruder, R., Buckle, P., Carayon, P., Falzon, P., Marras, W. S., Wilson, J. R., \& Van Der Doelen, B. (2012). A strategy for human factors/ergonomics: developing the discipline and profession. Ergonomics, 55(4), 377-395. https://doi.org/10.1080/00140139.2012.661087

Dwyer, J., \& Beck, J. (2020). Alcoa Earns Recognition in Annual Dow Jones Sustainability Indices. Retrieved May 24, 2021, from https://investors.alcoa.com/news-releases/news-releasedetails/2020/Alcoa-Earns-Recognition-in-Annual-Dow-Jones-Sustainability-

Indices/default.aspx

European Commission. Eurostat. (n.d.) EU trend of SDG 9 on industry, innovation, and infrastructure. Retrieved April 24, 2020, from https://ec.europa.eu/eurostat/statisticsexplained/pdfscache/63340.pdf

Firescu, V., \& Cândea, D. (2007). New Developments in Ergonomics - Support for Business Sustainability. Review of Management and Economic Engineering, 6 (3), 101-108.

Firescu, V., Crucianu, I., \& Gașpar M. (2020, September). Globalization and the acceptance of new technologies in our lives and in organizations. Paper presented at $7^{\text {th }}$ International Management Conference, Management Challenges Within Globalization, Cluj-Napoca, Romania.

Flokk. (n.d.). Ørsted Sustainable new office workspace based on recycling, reclaiming and reusing materials. Retrieved June 24, 2021, from https://www.flokk.com/global/projects/orsted

General Motors. (2020). Sustainability Report. Driving sustainable value. Retrieved May 24, 2021, from https://www.gmsustainability.com/

Guerin, E. (2018). Robots steal port jobs - but they also fight climate change. Retrieved May 20, 2021, from https://www.scpr.org/news/2018/01/22/79969/robots-that-steal-port-jobs-alsofight-climate-cha

Hitchcock, D., \& Willard, M. (2006). The business guide to sustainability. Practical strategies and tools for organizations. Earthscan.

International Ergonomics Association. (n.d.) What Is Ergonomics? Retrieved May 24, 2021, from https://iea.cc/what-is-ergonomics/

Ioannou, I., \& Serafeim, G. (2019). Corporate Sustainability: A Strategy? Retrieved May 24, 2021, from https://corpgov.law.harvard.edu/2019/02/12/corporate-sustainability-a-strategy/

Kadir, B., Broberg, O., \& Souza da Conceicao, C. (2019). Current research and future perspectives on human factors and ergonomics in Industry 4.0. Computers \& Industrial Engineering, 137, 106004. https://doi.org/10.1016/j.cie.2019.106004

Kinzel, H. (2016, September). Industry 4.0 - Where Does This Leave the Human Factor? Paper presented at the $27^{\text {th }}$ Annual Conference of Human Dignity and Humiliation Studies 'Cities at Risk - From Humiliation to Dignity'. Dubrovnik, Croatia. 
Müller, J. M., Kiel, D., \& Voigt, K. I. (2018). What Drives the Implementation of Industry 4.0? The Role of Opportunities and Challenges in the Context of Sustainability. Sustainability, 10, 247. https://doi.org/10.3390/su10010247

Nagy, J., Oláh, J., Erdei, E., Máté, D., \& Popp, J. (2018). The Role and Impact of Industry 4.0 and the Internet of Things on the Business Strategy of the Value Chain - The Case of Hungary. Sustainability, 10, 3491. https://doi.org/10.3390/su10103491

Ørsted. (2020). A sustainable build-out of green energy. Sustainability report. Retrieved June 24, 2021, from https://orsted.com/sustainability 2020

Pirelli. (2020). Annual report. The human dimension. Retrieved May 24, 2021, from https://corporate.pirelli.com/var/files2020/EN/PDF/PIRELLI_ANNUAL_REPORT_2020_E NG.pdf

S\&P Dow Jones Indices. (2020). Dow Jones Sustainability World Index. Retrieved May 24, 2021, from https://portal.csa.spglobal.com/survey/documents/DJSIComponentsWorld_2020_.pdf

S\&P Global. (2020). DJSI Industry Leaders. CSA Industry leaders as of 13 November 2020. Retrieved May 24, 2021, from https://www.spglobal.com/esg/csa/csa-resources/industryleaders

S\&P Global. (n.d.). $S \& P$ Global Sustainable 1. Retrieved May 24, 2021, from https://www.spglobal.com/esg/about/index

Sustainable Development Goals Knowledge Platform. (n.d.). Industry. Retrieved April 24, 2020, from https://sustainabledevelopment.un.org/topics/industry

Trefis. (2013, September 12). What Does Alcoa's Exit From Dow Jones Mean? Retrieved May 24, 2021, from https://www.nasdaq.com/articles/what-does-alcoas-exit-dow-jones-mean-201309-12

Zink, K. (2014). Designing sustainable work systems: The need for a systems approach. Applied Ergonomics, 45(1), 126-132. https://doi.org/10.1016/j.apergo.2013.03.023 